\title{
Perancangan Tata Letak Gudang dengan Metoda Class-Based Storage Studi Kasus CV. SG Bandung
}

\author{
Nita Puspita Anugrawati Hidayat \\ Fakultas Rekayasa Industri, \\ Institut Teknologi Telekomunikasi Bandung, Jl.Telekomunikasi no.1 Bandung \\ E-mail: nita.ph@gmail.com
}

\begin{abstract}
Abstrak - CV.XY-Bandung merupakan perusahaan konveksi yang memproduksi jilbab. Untuk dapat bersaing, perusahaan harus mampu meningkatkan produktivitas dan mengurangi biaya operasional perusahaan. Dari hasil pengamatan, CV. XY-Bandung belum memiliki tata letak yang baik. Hal ini terlihat dari cara penyimpanan bahan baku di gudang yang belum mengikuti kaidah tata letak gudang. Pada gudang bahan baku, kain diletakkan secara acak sehingga menyulitkan pencarian, kapasitas gudang bahan baku saat ini dikeluhkan tidak mencukupi kebutuhan. Parameter tata letak gudang bahan baku yang baik adalah dipenuhinya ruang secara maksimal dan pemenuhan terhadap permintaan bahan baku yang lebih cepat. Pada penelitian ini, metode class-based storage dan penggunaan rak, memisahkan kain berdasarkan jenis kain di gudang bahan baku mampu memberikan peningkatan kapasitas gudang. Dengan rancangan tata letak gudang bahan baku usulan dapat meningkatkan kapasitas gudang, sehingga mampu memberikan ruang kosong untuk 1600 polybag.
\end{abstract}

Abstract - CV. XY-Bandung is convection produsen that produce jilbab. To be able competing with others, produsen has to keep improving productivity and do cost efficiency. From observation, CV. XY-Bandung has not had a good layout. It is shown from raw material inventory in storage that has not using storage layout theory. In the storage of raw materials, fabrics are placed by random, make it difficult to search, and the storage of raw materials capacity is unable to fulfill demand. The good parameters for storage of raw materials are optimal utility and fulfillness of raw material demands faster. In this research, classbasedstorage method and shelf, separate fabrics are based on type of fabric in raw material storage that able to improving storage capacity. By proposes the design raw material storage layout, it should be able to increasing storage capacity, thus, it will be able to give space for 1600 polybag.

Keywords - layout, CRAFT algorithm, movement momen, class-based storage

\section{PENDAHULUAN}

$\mathrm{P}$ ersaingan dunia usaha kini makin ketat, setiap usaha dituntut untuk melakukan kegiatan usaha secara efektif dan efisien. Dalam suatu pabrik, efektif dan efisien dapat dilihat melalui berbagai aspek diantaranya sistem penyimpanan material. Misalnya gudang bahan baku, ketersediaan bahan baku pada waktu yang tepat dan jumlah yang tepat dapat mempengaruhi kelancaran proses produksi. Oleh karena itu, dibutuhkan sistem penyimpanan yang baik dalam gudang.

CV. XY merupakan perusahaan yang bergerak di industri garmen dengan produk busana muslim. Saat ini CV. XY-Bandung memiliki 5 pabrik yang berlokasi di Bandung. Pabrik yang diamati pada penelitian ini adalah pabrik yang memproduksi aneka kerudung yang dilengkapi dengan gudang bahan baku berupa kain. Gudang ini menyimpan dan menyuplai kebutuhan bahan baku kain untuk seluruh pabrik CV. XY. Saat ini tata letak gudang menggunakan metode randomized storage, yaitu kain ditempatkan secara acak tanpa aturan tertentu. Hal ini menyebabkan proses pencarian kain 
menjadi sulit. Selain itu, kain ditempatkan di sembarang tempat seperti di jalur material handling, serta kapasitas yang dimiliki gudang belum dimanfaatkan secara optimal sehingga terjadi penurunan kapasitas gudang sebenarnya. Berdasarkan fakta tersebut perlu dilakukan perancangan kebijakan penyimpanan dan perancangan tata letak gudang agar menjadi lebih baik.

Penelitian ini dimaksudkan untuk merancang perbaikan tata letak gudang bahan baku dengan menggunakan metode class-based storage pada $\mathrm{CV}$. XY dengan tujuan peningkatan utilisasi kapasitas gudang dan percepatan pemenuhan pemintaan kain. Metode class-based storage digunakan dalam perbaikan tata letak gudang bahan baku di CV. XY dengan pertimbangan kain yang disimpan di gudang bahan baku memiliki karakteristik tertentu yang mampu membedakan antara kain yang satu dengan lainnya. Sehingga perlu dilakukan penelitian lebih lanjut mengenai pemilahan dan penyimpan bahan baku tersebut.

Adapun batasan masalah pada penelitian ini adalah:

a. Data yang digunakan merupakan data produksi yang berlangsung saat penelitian yaitu pada bulan Juni-Desember 2010.

b. Tidak melakukan perhitungan biaya perbaikan tata letak.

c. Tidak melakukan perubahan terhadap sistem produksi maupun urutan proses produksi.

d. Dalam perhitungan jarak menggunakan jarak rektilinier.

e. Tidak ada penambahan atau pengurangan fasilitas atau departemen selama penelitian berlangsung.

f. Tidak ada penambahan jenis produk baru selama penelitian berlangsung.

\section{TINJAUAN PUSTAKA}

Gudang merupakan tempat penyimpanan material yang diperlukan untuk proses produksi, material tersebut akan terus disimpan hingga siap diproses sesuai dengan jadwal produksi atau order konsumen. Adapun tujuan dari kegiatan penyimpanan material adalah sebagai berikut [1]:
a. Untuk menyeimbangkan antara kemampuan produksi dengan demand konsumen
b. Untuk memberikan suatu customer service yang spesifik
c. Untuk menambah nilai pada produk

Aktivitas yang umumnya dilakukan berkaitan dengan penyimpanan material dalam gudang, adalah Receiving, Prepacking, Put-away, Storage, Order picking, Packaging, Sortation and accumulation, Packing and Shipping [2]. Dalam perancangan tata letak gudang terdapat beberapa prinsip yang umum dijadikan sebagai acuan, yaitu: Popularity, Similarity, Size, Characteristics dan Space utilization. Beberapa karakteristik komponen yang penting yaitu: Perishable materials (komponen yang mudah rusak), Oddly shaped and crushable items (komponen bentuk khusus dan mudah rusak), Hazarduous materials (komponen berbahaya), Security items (komponen dengan pengamanan khusus) dan Compatibility (kecocokan/kesesuaian).

Penempatan barang adalah kegiatan yang berhubungan dengan berdasarkan apa suatu barang ditempatkan dalam gudang. Kebijakan penempatan barang ini berdampak pada waktu transportasi yang dibutuhkan dan proses pencarian atau penelusuran barang. Berikut ini adalah jenis-jenis kebijakan penempatan barang [1]:

a. Random storage

Yaitu penempatan barang berdasarkan tempat yang paling dekat dengan lokasi input barang, implikasi kebijakan ini adalah waktu pencarian barang lebih lama. Random storage memerlukan sistem informasi yang baik, umumnya cara ini dilakukan pada sistem AS/RS (Automated Storage/Retrievel System).

b. $\quad$ Fixed storage atau dedicated storage

Aplikasi kebijakan yang menempatkan satu jenis bahan atau material di tempat yang khusus hanya untuk bahan atau material tersebut. Kebijakan ini akan mengurangi waktu dalam pencarian barang, namun ruang yang dibutuhkan menjadi kurang efisien karena ruang kosong untuk satu bahan atau material tidak diperbolehkan untuk ditempati bahan atau material lainnya.

c. Class-based storage

Yaitu penempatan bahan atau material berdasarkan atas kesamaan suatu jenis bahan atau material kedalam suatu kelompok. Kelompok ini nantinya akan ditempatkan pada suatu lokasi khusus pada gudang. Kesamaan bahan atau material pada suatu kelompok, bisa dalam bentuk kesamaan jenis item atau kesamaan pada suatu daftar pemesanan konsumen. 


\section{d. Shared storage}

Penempatan beberapa bahan atau material dalam satu area yang dikhususkan untuk bahan atau material tersebut. Kebijakan ini mengurangi jumlah kebutuhan luas gudang dan mampu peningkatkan utilisasi area penempatan persediaan.

\section{METODOLOGI PENELITIAN}

Pada penelitian ini dibutuhkan data tata letak gudang bahan baku existing, karakteristik kain, data jadwal pemesanan dan permintaan kain, serta aliran bahan di gudang bahan baku. Data tata letak gudang bahan baku digunakan untuk mengetahui tata letak saat ini meliputi dimensi rak yang digunakan, gang, peralatan material handling yang digunakan, dimensi mesin, serta kebijakan yang diterapkan dalam penempatan kain. Data karakteristik kain adalah data mengenai ciri-ciri yang dimiliki tiap kain yang disimpan. Data ini digunakan untuk penentuan dalam penempatan dengan metode class based storage. Data jadwal dan jumlah pemesanan dan permintaan barang digunakan untuk mengetahui kain jumlah dan permintaan kain di gudang yang juga dapat mempengaruhi kebijakan penempatan barang. Data aliran bahan digunakan untuk mengetahui aliran kain sejak datang dari supplier hingga dikeluarkan untuk diproduksi. Keempat data yang digunakan dalam dalam perancangan tata letak gudang bahan baku diperoleh melalui pengamatan dan pengukuran langsung di lapangan, serta berdasarkan data historis yang dimiliki perusahaan.

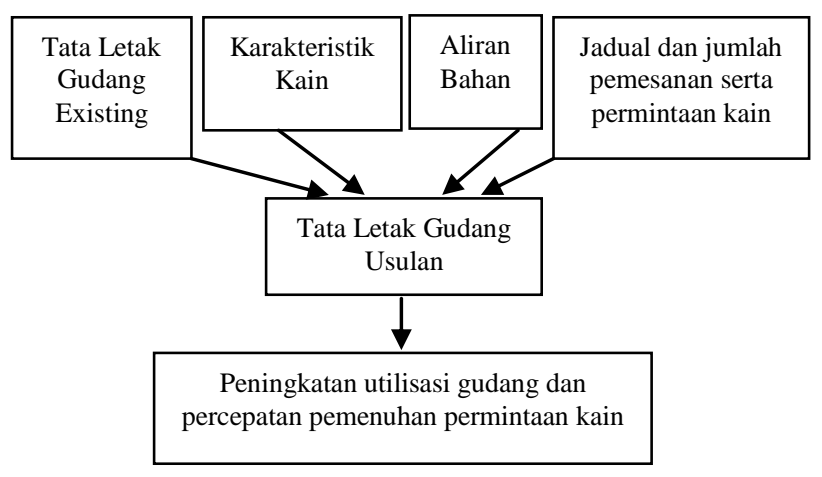

Gambar 1. Model Konseptual
Adapun tahapan dan urutan proses penelitian yang dilakukan sebagai berikut: pertama tahap pendahuluan, yaitu pengamatan awal mengenai permasalahan utama di lapangan hingga diperoleh pendefinisian awal mengenai permasalahan yang diangkat serta melakukan studi tentang hal-hal yang terkait dengan tata letak gudang.

Kedua adalah tahap pengumpulan dan pengolahan data. Pada tahap ini dilakukan pengumpulan data yang mendukung dalam proses penelitian mengenai tata letak gudang bahan baku, diantaranya data tata letak gudang existing meliputi luas dan tinggi gudang, alat-alat yang terdapat di gudang bahan baku beserta dimensinya. Data ini digunakan sebagai data awal dalam evaluasi tata letak gudang dan dijadikan sebagai acuan dalam perbaikan. Data karakteristik kain di gudang, data ini menjabarkan ciri-ciri yang dimiliki oleh kain seperti warna, jenis, supplier, dan dimensi dari bahan baku. Data ini digunakan sebagai data masukan dalam perbaikan tata letak gudang bahan baku dengan metode class based storage. Data aliran bahan di gudang bahan baku, data ini menunjukkan aliran bahan baku di gudang bahan baku sejak masuk untuk disimpan hingga digunakan. Data ini digunakan sebagai data masukan dalam perbaikan tata letak gudang bahan baku. Data jadwal dan jumlah pemesanan dan permintaan kain, data ini menunjukkan jumlah kain yang disimpan dan penempatan kain di gudang bahan baku . Data ini akan dijadikan sebagai data masukan untuk perbaikan tata letak gudang. Pada pengolahan data dilakukan perancangan kebijakan berdasarkan prinsip perancangan tata letak gudang, analisis kebijakan yang akan digunakan dalam penempatan kain pada tata letak gudang usulan.

Tahap ketiga adalah analisa terhadap tata letak gudang bahan baku usulan yang telah diperoleh dengan kebijakan penempatan yang baru berdasarkan metode class based storage serta tata letak fasilitas yang ada di gudang bahan baku. Sehingga dapat memperlancar proses yang terdapat di gudang bahan baku dan peningkatan kapasitas gudang.

Terakhir adalah tahap Kesimpulan dan Saran, pada tahap ini akan ditarik kesimpulan yang merujuk kembali kepada tujuan dari penelitian ini. Selain itu, akan diberikan saran untuk perbaikan dan pengembangan lebih lanjut terhadap penelitian sejenis. 


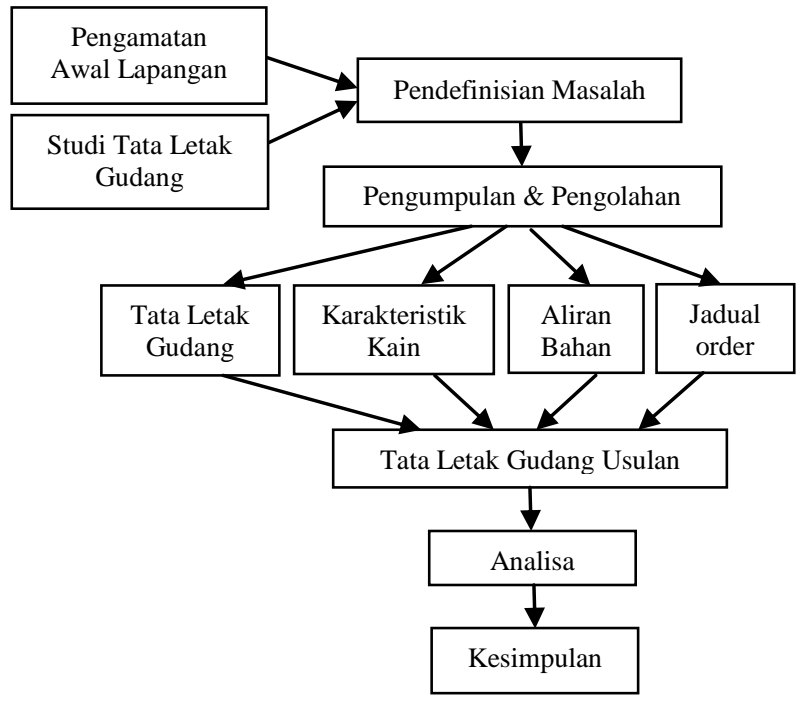

Gambar 2: Tahapan Penelitian

\section{HASIL DAN PEMBAHASAN}

Berikut ini adalah layout gudang bahan baku saat ini:

Ukuran dari gudang bahan baku CV. XY-Bandung adalah 45,6 m x 22,6 m x $3 \mathrm{~m}$. Proses keluar masuk bahan baku melalui sebuah pintu berukuran $2 \mathrm{~m} \mathrm{x}$ 2,5 m. Selain itu, untuk menjamin kelancaran kegiatan pergudangan dalam gudang bahan baku terdapat beberapa fasilitas. Fasilitas tersebut adalah sebagai berikut:

a. Tempat penimbangan

Pada tempat ini merupakan lokasi penumpukan kain yang dikirim oleh supplier. Pada lokasi ini terdapat alat timbang dengan dimensi $1,2 \mathrm{~m} \mathrm{x}$ $0,5 \mathrm{~m} \mathrm{x} 1,42 \mathrm{~m}$.

b. Inspeksi

Setelah kain ditimbang dan sesuai dengan nota yang dikirim. Kain selanjutnya diinspeksi dengan menggunakan mesin inspeksi. Mesin yang dimiliki berjumlah 5 mesin berdimensi 1,2 $\mathrm{m} \times 2,7 \mathrm{~m}$ x $1,5 \mathrm{~m}$. Setiap mesin dilengkapi pula dengan sebuah meja dengan dimensi $2,7 \mathrm{~m}$ x 0,6 $\mathrm{m} \times 0,5 \mathrm{~m}$.

c. Penyimpanan kain

Tempat penyimpanan kain dibagi menjadi beberapa bagian yaitu kain yang belum diinspeksi, lolos inspeksi, dan kain yang tidak lolos inspeksi. Lokasi penyimpanan tersebar tanpa adanya ketentuan tertentu.

\section{d. Administrasi}

Bagian administrasi merupakan bagian yang mengelola administrasi di gudang seperti data keluar dan masuknya kain di gudang bahan baku.

Gambar 3 pada lampiran menunjukan tata letak awal dari gudang bahan baku pada CV. XYBandung. Sedangkan Gambar 4 pada lampiran menunjukkan diagram aliran bahan baku dalam gudang. Dari gambar tersebut akan terlihat arah pergerakan bahan baku saat memenuhi order pengiriman ke lantai produksi.

Kain yang datang dari supplier selanjutnya ditimbang untuk memastikan antara berat serta jenis yang ada di nota dengan yang dikirmkan. Kain selanjutnya disimpan di sembarang tempat yang tersedia untuk menunggu giliran pengecekan. Selanjutnya, kain dicek dengan mesin inspeksi untuk melihat mutu dari kain yang dikirmkan. Jika kain dianggap cacat dan harus dikembalikan, maka kain akan diletakkan di bagian kain tidak lolos inspeksi. Jika kain dianggap baik maka disimpan pada tempat penyimpanan kain yang kosong.

\subsection{Karakteristik Kain}

Kain yang disimpan digudang bahan baku CV. XYBandung secara garis besar terdapat 2 jenis kain yaitu kain woven dan kain knitting. Kain-kain tersebut disimpan di dalam gudang dalam sebuah polybag. Setiap polybag memiliki berat sebesar 25 $\mathrm{kg}$ dan berukuran $50 \mathrm{~cm}$ x $30 \mathrm{~cm}$ x $90 \mathrm{~cm}$. Dalam penyimpanannya kain woven dan knitting tidak memiliki perlakuan khusus. Kedua jenis kain tersebut diletakkan di sembarang tempat yang tersedia.

Untuk mendukung kegiatan aliran bahan di gudang bahan baku terdapat beberapa alat material handling. Alat material handling yang digunakan yaitu sebagai berikut:

a. 1 buah Kereta dorong dengan dimensi $2 \mathrm{~m} \times 1$ $\mathrm{m} \times 80 \mathrm{~cm}$.

b. 1 buah Handclift dengan dimensi $1 \mathrm{~m} \mathrm{x} 70 \mathrm{~cm}$ $\mathrm{x} 80 \mathrm{~cm}$.

c. Manusia. Manusia yang dimaksud disini adalah semua tenaga kerja yang bekerja digudang. Manusia digunakan jika kain yang dibawa tidak terlalu banyak atau kereta dorong dan handclift sedang digunakan. 


\subsection{Jadwal Pemasukan dan Pengeluaran Kain}

Setiap harinya kain selalu datang dari supplier dan juga keluar untuk diproduksi. Pengiriman dari supplier dan pengiriman ke produksi berlangsung setiap hari dan setiap waktu. Berikut ini adalah data persediaan kain saat ini, data keluar dan masuk kain di gudang bahan baku CV. XY-Bandung setiap bulan. (sumber: data internal CV. XY-Bandung).

Selanjutnya, Data pada Tabel 1 akan digunakan untuk penentuan kapasitas gudang saat ini, sedangkan data pada Tabel 2 akan digunakan untuk penentuan letak kain karena kain dengan permintaan tertinggi harus diletakkan dekat dengan pintu keluar masuk gudang.

Tabel 1, menunjukan jumlah persediaan bahan baku untuk periode Juni-Juli, sementara tabel 2 adalah data pemakaian bahan baku selama periode Juni-Juli. Dari data tersebut dapat terlihat status persediaan bahan baku selama periode Juni-Juli

\subsection{Kebutuhan Produk}

Produk yang diproduksi oleh CV. XY-Bandung melewati beberapa tahapan proses. Pada beberapa tahapan proses, terdapat scrap yang tentunya akan menambah jumlah produk yang harus disiapkan. Data berikut ini akan menentukan kebutuhan produk yang harus disiapkan dari awal produksi, sehingga dapat memenuhi permintaan.

Jumlah yang diminta adalah permintaan dari produk yang harus dipenuhi, sedangkan jumlah yang disiapkan diperoleh dengan rumus sebagai berikut:

Jumlah yang harus disiapkan $=\frac{\text { jumlah yang diminta }}{1-\% \text { scrap }}[3]$

Satuan produk yang dipindahkan dijabarkan dalam 2 satuan yaitu piecies dan polybag. Perpindahan antar departemen dilakukan dalam satuan polybag.

Dengan menggunakan rumusan tersebut dapat diperloleh jumlah kebutuhan produk yang tertera di tabel 3 pada lampiran. Dengan diketahui jumlah kebutuhan produk dapat diketahui berapa jumlah material yang harus disiapkan dan akhirnya akan diperoleh jumlah kebutuhan gudang yang tertera pada tabel 4
Tabel 1. Persediaan Bahan Baku CV. XY-Bandung Periode Juni-Juli

\begin{tabular}{llc}
\hline \multicolumn{1}{c}{ Jenis } & \multicolumn{1}{c}{ Nama } & \multicolumn{1}{c}{$\begin{array}{c}\text { Bulan } \\
\text { Juni-Juli }\end{array}$} \\
\hline $\begin{array}{l}\text { Kaos balon } \\
\text { printing } \\
\text { Kaos blister }\end{array}$ & $\begin{array}{l}\text { Kaos balon printing Foil } \\
\text { Emas c/Hitam (Gunawan) } \\
\text { Kos Blister c/Beidge- } \\
\text { Coklat (Gunawan) }\end{array}$ & 3 \\
Kaos blister & $\begin{array}{l}\text { Kaos Blister c/Coklat } \\
\text { VH-Putih (Gunawan) }\end{array}$ & 2 \\
Kaos blister & $\begin{array}{l}\text { Kaos Blister c/Hijau } \\
\text { Army-Putih (Gunawan) }\end{array}$ & 1 \\
Kaos blister & $\begin{array}{l}\text { Kaos Blister c/Sky Blue- } \\
\text { Navy (Gunawan) }\end{array}$ & 5 \\
Kaos CF 043 & $\begin{array}{l}\text { Kaos CF 043 c/Biru Muda } \\
\text { (CGNP) }\end{array}$ & 1 \\
$\begin{array}{l}\text { Kaos Corduray c/Abu } \\
\text { corduray }\end{array}$ & (JvaEtnic) & 0 \\
\hline
\end{tabular}

Tabel 2. Pemakaian Bahan Baku CV. XY-Bandung Periode Juni-Juli

\begin{tabular}{llc}
\hline \multicolumn{1}{c}{ Jenis } & \multicolumn{1}{c}{ Nama } & $\begin{array}{c}\text { Bulan } \\
\text { Juni-Juli }\end{array}$ \\
\hline $\begin{array}{l}\text { Kaos } \\
\text { corduray }\end{array}$ & $\begin{array}{l}\text { Kaos Corduray c/Cokpi } \\
\text { (Raphatex) }\end{array}$ & 14 \\
$\begin{array}{l}\text { Kaos } \\
\text { corduray }\end{array}$ & $\begin{array}{l}\text { Kaos Corduray } \\
\text { c/Hitam(Raphatex) }\end{array}$ & 9 \\
$\begin{array}{l}\text { Kaos } \\
\text { corduray }\end{array}$ & $\begin{array}{l}\text { Kaos Corduray c/Hitam } \\
\text { (Raphatex) }\end{array}$ & 24 \\
\hline
\end{tabular}

Tabel 4. Jumlah Kebutuhan Gudang

\begin{tabular}{lc}
\hline \multicolumn{1}{c}{ Nama } & Kebutuhan \\
\hline $\begin{array}{l}\text { Kaos balon printing foil emas c/Hitam } \\
\text { (Gunawan) }\end{array}$ & 3 \\
Kaos blister c/Beige-Coklat (Gunawan) & 1 \\
Kaos blister c/Coklat VH-Putih & 2 \\
(Gunawan) & \\
Kaos blister c/Hijau army-Putih & 1 \\
(Gunawan) & \\
Kaos blister c/Sky blue-Navy (Gunawan) & 4 \\
Kaos CF 043 c/Birumuda(CGNP) & 1 \\
Kaos curdoray c/Abu (Java Etnic) & 10 \\
Kaos curdoray c/Abu (Raphatex) & 5 \\
Kaos curdoray c/Abu (Raphatex) & 55 \\
\hline
\end{tabular}

\subsection{Tata Letak Gudang Bahan Baku}

Saat ini kain yang diletakkan di gudang bahan baku diletakkan secara acak dengan menempati ruang kosong yang tersedia. Sehingga jarak yang ditempuh untuk mengambil kain apapun jenisnya pada kondisi saat ini adalah dari pintu keluar masuk 
ke seluruh lokasi penyimpanan kain lolos inspeksi yaitu $827,48 \mathrm{~m}^{2}$. Jarak tempuh pada setiap jenis kain adalah sama karena petugas gudang bahan baku diasumsikan tidak mengetahui kain yang dicari, sehingga harus mencari pada gudang keseluruhan.

Dalam penentuan kebutuhan ruang digunakan jumlah pembelian, pengembalian, dan saldo awal dari tiap jenis kain. Hal ini dikarenakan kain harus disimpan dalam jumlah yang besar mengingat jarak dari pemesanan dari supplier sampai kain dikirimkan kurang lebih selama 2 bulan. Selanjutnya dari tiap periode dirata-ratakan untuk menentukan kapasitas yang dibutuhkan dalam gudang. Kapasitas yang dibutuhkan diperoleh dengan menghitung jumlah polybag yang harus disimpan.

Total keseluruhan jumlah polybag yang harus disimpan adalah 8.930 polybag yang terdiri dari kain knitting dan kain woven (data selengkapnya terlampir).

\subsection{Tata Letak Gudang Usulan}

Dalam perancangan tata letak gudang usulan metode penyimpanan yang digunakan adalah class based storage yang dikombinasikan dengan randomized storage. Metode class based storage akan mengelompokkan kain berdasarkan jenis kain yaitu kain woven dan kain knitting. Selanjutnya dari tiap jenis kain tersebut dipecah lagi menjadi beberapa jenis kain kembali. Dari lokasi penyimpanan tiap jenis kain lalu ditetapkan metode randomized storage, artinya kain dengan jenis yang telah ditetapkan bebas ditempatkan dimana saja, tanpa ada pemberian ruang yang lebih khusus.

Dalam urutan peletakan jenis kain diurutkan berdasarkan rata-rata permintaan dari tiap jenis kain. Jenis kain yang paling tinggi permintannya diletakkan paling dekat dengan pintu keluar masuk.

Area pada gudang bahan baku selanjutnya dibagi menjadi 6 area yaitu area penyimpanan kain lolos inspeksi, area penyimpanan kain sebelum diinspeksi, area kain yang harus dikembalikan, area penimbangan, area administrasi, dan area mesin inspeksi. Sedangkan lokasi pembuatan tudung jilbab, dipindahkan ke area cutting gelaran karena masih terdapatnya ruang kosong yang tersedia.
Setiap rak penyimpanan disusun menjadi 2 tingkat dengan tinggi penyimpanan maksimal untuk tingkat 1 adalah $1,5 \mathrm{~m}$ sedangkan untuk tingkat 2 adalah $1,2 \mathrm{~m}$.

Kapasitas setiap rak penyimpanan diperoleh dengan memperhitungkan dimensi dari polybag yang diletakkan secara horizontal.

Rak penyimpanan $1=(1,75 / 0,9) \times(45,6 / 0,5) \times$ $(2,7 / 0,3)=1.642$ polybag

Rak penyimpanan $2=(1,75 / 0,9) \times(40 / 0,5) \times$ $(2,7 / 0,3)=1.440$ polybag

Rak penyimpanan $3=(1,75 / 0,9) \times(40 / 0,5) \times$ $(2,7 / 0,3)=1.440$ polybag

Rak penyimpanan $4=(1,75 / 0,9) \times(40 / 0,5) \times$ $(2,7 / 0,3)=1.440$ polybag

Rak penyimpanan $5=(1,75 / 0,9) \times(40 / 0,5) \times$ $(2,7 / 0,3)=1.440$ polybag

Rak penyimpanan $6=(1,75 / 0,9) \times(40 / 0,5) \times$ $(2,7 / 0,3)=1.440$ polybag

Rak penyimpanan $7=(1,75 / 0,9) \times(34 / 0,5) \times$ $(2,7 / 0,3)=1.224$ polybag

Rak penyimpanan $8=(1,75 / 0,9) \times(15 / 0,5) \times$ $(2,7 / 0,3)=540$ polybag

Area sebelum inspeksi $=(1,75 / 0,9) \times(6 / 0,5) \mathrm{x}$ $(2,7 / 0,3)=200$ polybag

Area retur $=(2,7 / 0,9) \times(25 / 0,5) \times 3=450$ polybag.

Gang antar rak diberikan selebar 1,15 m. Hal ini berdasarkan lebar maksimal dari alat material handling yaitu $1 \mathrm{~m}$, karena pada proses penyimpanan sebagian besar menggunakan kereta dorong atau handclift. Sedangkan pada proses pengambilan kain sebagian besar menggunakan tenaga manusia.

Tabel 5 dan 6 menunjukkan data mengenai permintaan kain woven dan knitting, tabel 7 merupakan data kapasitas area penyimpanan kain. Tabel 8 menunjukan area penyimpanan berupa kebijakan jenis kain yang dapat disimpan pada rak 3. Berdasarkan data-data tersebut dapat diketahui kebutuhan area penyimpanan kain, yang pada 
akhirnya memunculkan rancangan tata letak gudang usulan seperti gambar 5 pada lampiran.

Dalam penyimpanan kain prosedur yang dilakukan adalah sebagai berikut:

a. Kain disimpan secara berurut menurut Tabel 7 dalam tiap rak, dengan urutan pertama diletakkan paling depan dan dilanjutkan hingga ke belakang.

b. Tiap jenis kain diisi dengan cara memenuhi ruang hingga keatas, setelah terpenuhi selanjutnya mengisi kembali dari bawah. Setiap jenis kain diberi sekat untuk membedakan pengelompokan dengan jenis lainnya.

Tabel 5. Permintaan Kain Woven

\begin{tabular}{lc}
\hline \multicolumn{1}{c}{ Jenis } & $\begin{array}{c}\text { Rata-rata } \\
\text { Permintaan }\end{array}$ \\
\hline Kain finedo 2408 L58” & 1 \\
Kain jet black & 1 \\
Kain knitting burn out print & 1 \\
Kain linen rami tipis (Makmur Jaya) & 1 \\
Kain M2421 & 1 \\
Kain PCK 0311 & 1 \\
Kain PCK 0312 & 1 \\
Kain silk & 1 \\
Kain DYE 55289 & 2 \\
Kain Java silver & 2 \\
\hline
\end{tabular}

Tabel 6. Permintaan Kain Knitting

\begin{tabular}{lc}
\hline \multicolumn{1}{c}{ Jenis } & $\begin{array}{c}\text { Rata-rata } \\
\text { permintaan }\end{array}$ \\
\hline Kaos model striper/model spandex & 1 \\
Kaos PE 30 & 1 \\
Kaos Rib Cotton & 1 \\
Kaos blister & 2 \\
Kaos jaquard salur motif 2 & 2 \\
Kaos spandex baloon & 2 \\
Kaos jaquard motif merak & 9 \\
\hline
\end{tabular}

Tabel 7. Kapasitas Area Penyimpanan Kain

\begin{tabular}{lc}
\hline \multicolumn{1}{c}{ Area Penyimpanan } & Kapasitas \\
\hline Rak penyimpanan 1 & 1.642 \\
Rak penyimpanan 2 & 1.440 \\
Rak penyimpanan 3 & 1.440 \\
Rak penyimpanan 4 & 1.440 \\
Rak penyimpanan 5 & 1.440 \\
Rak penyimpanan 6 & 1.440 \\
Rak penyimpanan 7 & 1.224 \\
Rak penyimpanan 8 & 540 \\
Area sebelum inspeksi & 200 \\
Area retur & 450 \\
\hline
\end{tabular}

Tabel 8. Penempatan Kain

\begin{aligned} \hline Area Penyimpanan & \multicolumn{1}{c}{ JenisKain yang Disimpan } \\ \hline Rak Penyimpanan 3 & Kain TR Chenile \\ & Kain Finex Polos 6399 L 44 \\ & Kain Hip Hop 58” \\ & Kain KCD \\ & Kain PRSTN 24 \\ & Kain CDB \\ & Kaos rib cotton \\ & Kaos PE 30 \\ & Kaos model striper/model \\ & spandex \\ & Kaos spandex balon \\ & Kaos jaquard salur motif 2 \\ & Kaos blister \\ & Kaos jaquard salur motif \\ & merak \\ & \end{aligned}

\subsection{Analisis}

Dalam perancangan tata letak fasilitas dibutuhkan luas lantai yang sesuai untuk proses produksi jilbab. Kebutuhan ruangan turut memperhatikan allowance yang dibutuhkan oleh tiap fasilitas seperti allowance operator, material, dan material handling. Allowance-allowance tersebut tentunya juga membutuhkan sejumlah area untuk menampungnya.

Pada tata letak gudang bahan baku, total polybag yang harus disimpan disimpan adalah 8.766 polybag. Dengan perancangan tata letak gudang bahan baku baru yaitu dengan penggunaan rak untuk pemanfaatan area vertical, dapat menampung 11.256 polybag. Sehingga, dapat disimpulkan bahwa dengan perancangan tata letak gudang bahan baku yang baru dapat memennuhi kebutuhan kain yang disimpan. Kelebihan area dapat dimanfaatkan untuk mengatasi pemesanan yang berlebih, melihat lamanya lead time dalam pemesanan kain.

\section{KESIMPULAN}

Berdasarkan penelitian yang telah dilakukan, dapat disimpulkan bahwa pada tata letak gudang usulan digunakan rak sebagai penyimpanan sehingga dapat menambah kapasitas gudang. Dengan penggunaan rak ini terdapat kapasitas cadangan gudang yaitu sebanyak 1.600 polybag. Dengan kebijakan penempatan class-based storage, kain dikelompokkan berdasarkan jenisnya dan diurutkan menurut jumlah permintaannya. Kain dengan permintaan terbesar diletakkan paling dekat dengan 
pintu keluar masuk. Sehingga mempercepat pencarian kain karean tidak perlu mencari ke seluruh gudang, melainkan cukup mencari pada rak dimana jenis kain ditempatkan.

\section{DAFTAR PUSTAKA}

[1] Dwiyanto, A.,Perancangan Tata Letak Gudang Barang Jadi di PT. Toa Galva Industries, Bandung: Institut Teknologi Bandung, 2008.

[2] Tompkins, J. A., White, J. A., \& Tanchoco, J. M.,Facilities Planning (Fourth ed.), USA: John Wiley \& Sons, Inc., 1996.

[3] Wignjosoebroto, S.,Tata Letak Pabrik dan Pemindahan Bahan, Surabaya: Guna Widya, 1996.

\section{Lampiran}

Tabel 3. Kebutuhan Produk

\begin{tabular}{|c|c|c|c|c|c|c|}
\hline \multirow[t]{2}{*}{ No. } & \multirow[t]{2}{*}{ Nama Departemen } & \multirow{2}{*}{$\begin{array}{c}\text { Scrap } \\
(\%)\end{array}$} & \multicolumn{2}{|c|}{$\begin{array}{c}\text { Jumlah yang } \\
\text { Diminta }\end{array}$} & \multicolumn{2}{|c|}{$\begin{array}{c}\text { Jumlah yang } \\
\text { Disiapkan }\end{array}$} \\
\hline & & & Pcs & Polybag & Pcs & Polybag \\
\hline 1 & Gudang bahan baku & 0 & 4.203 & 45 & 4.203 & 45 \\
\hline 2 & Departemen cutting & 3 & 4.080 & 44 & 4.203 & 45 \\
\hline 3 & Departemen sablon & 0 & 788 & 8 & 788 & 8 \\
\hline 4 & Departemen loading & 0 & 4.111 & 44 & 4.111 & 44 \\
\hline 5 & Tempat jilbab setengah jadi 1 & 0 & 2.250 & 24 & 2.250 & 24 \\
\hline 6 & Tempat jilbab setengah jadi 2 & 0 & 1.861 & 20 & 1.861 & 20 \\
\hline 7 & Departemen sewing & 2 & 4.000 & 43 & 4.080 & 44 \\
\hline 8 & Departemen neci & 0 & 4.000 & 43 & 4.000 & 43 \\
\hline 9 & Bartek & 0 & 3.000 & 32 & 3.000 & 32 \\
\hline 10 & Pemasangan tali & 0 & 750 & 8 & 750 & 8 \\
\hline 11 & Departemen bordir & 0 & 4.000 & 43 & 4.000 & 43 \\
\hline 12 & Pembersihan bordir & 0 & 4.000 & 43 & 4.000 & 43 \\
\hline 13 & Steam & 0 & 250 & 3 & 250 & 3 \\
\hline 14 & QC final & 0 & 4.000 & 43 & 4.000 & 43 \\
\hline 15 & Departemen finishing & 0 & 4.000 & 43 & 4.000 & 43 \\
\hline
\end{tabular}




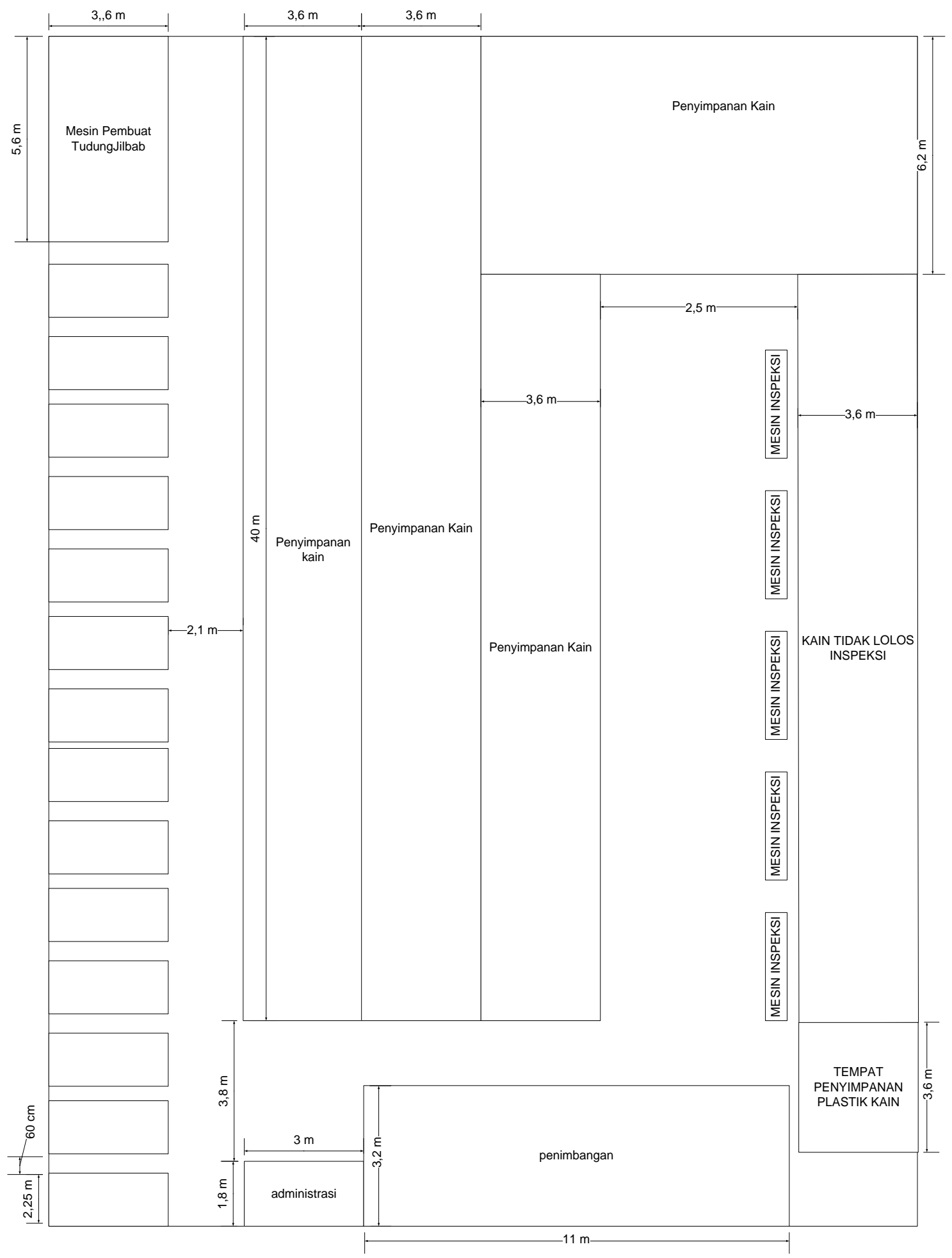

Gambar 3. Tata Letak Gudang Bahan Baku 


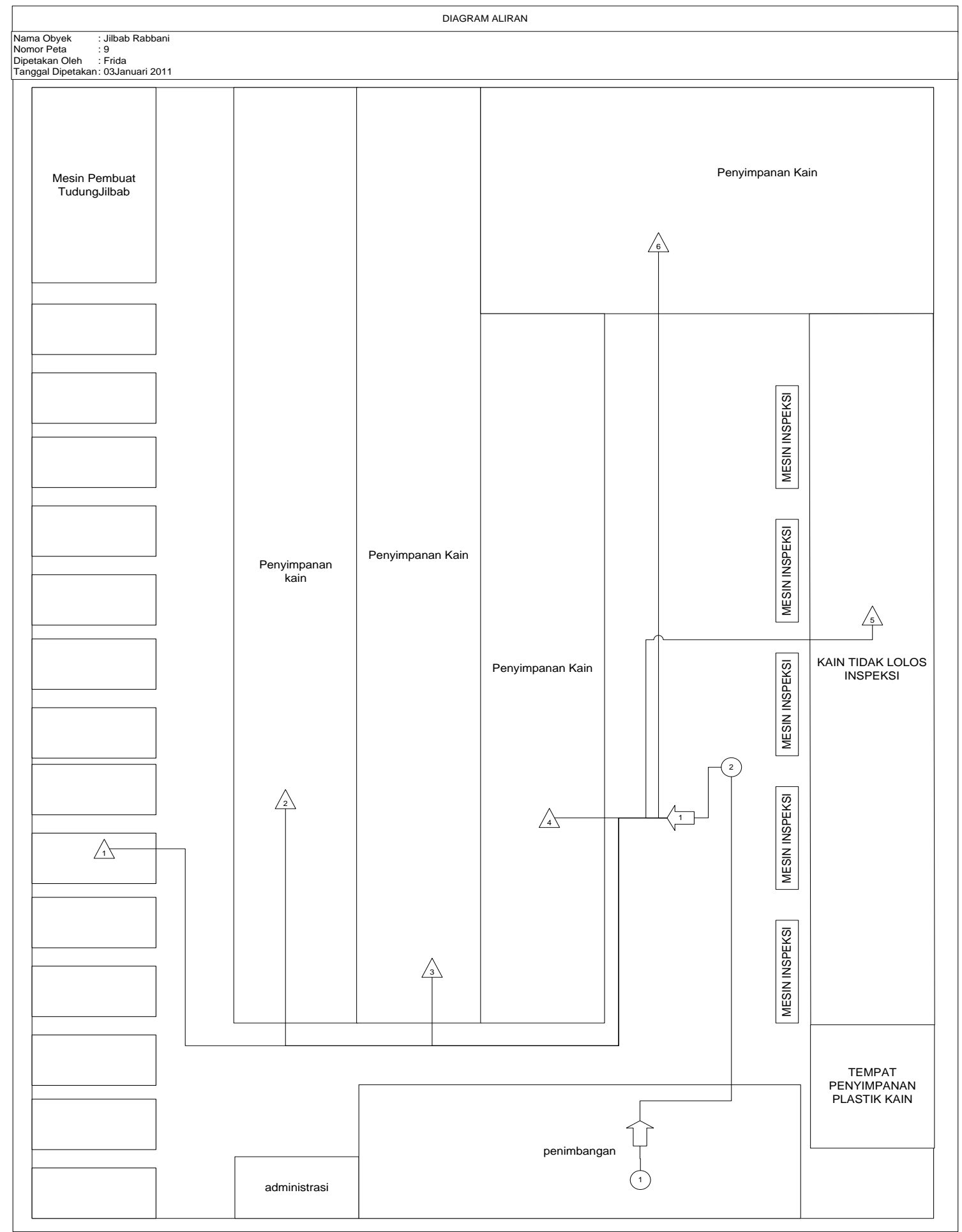

Gambar 4. Diagram Aliran Gudang Bahan Baku 


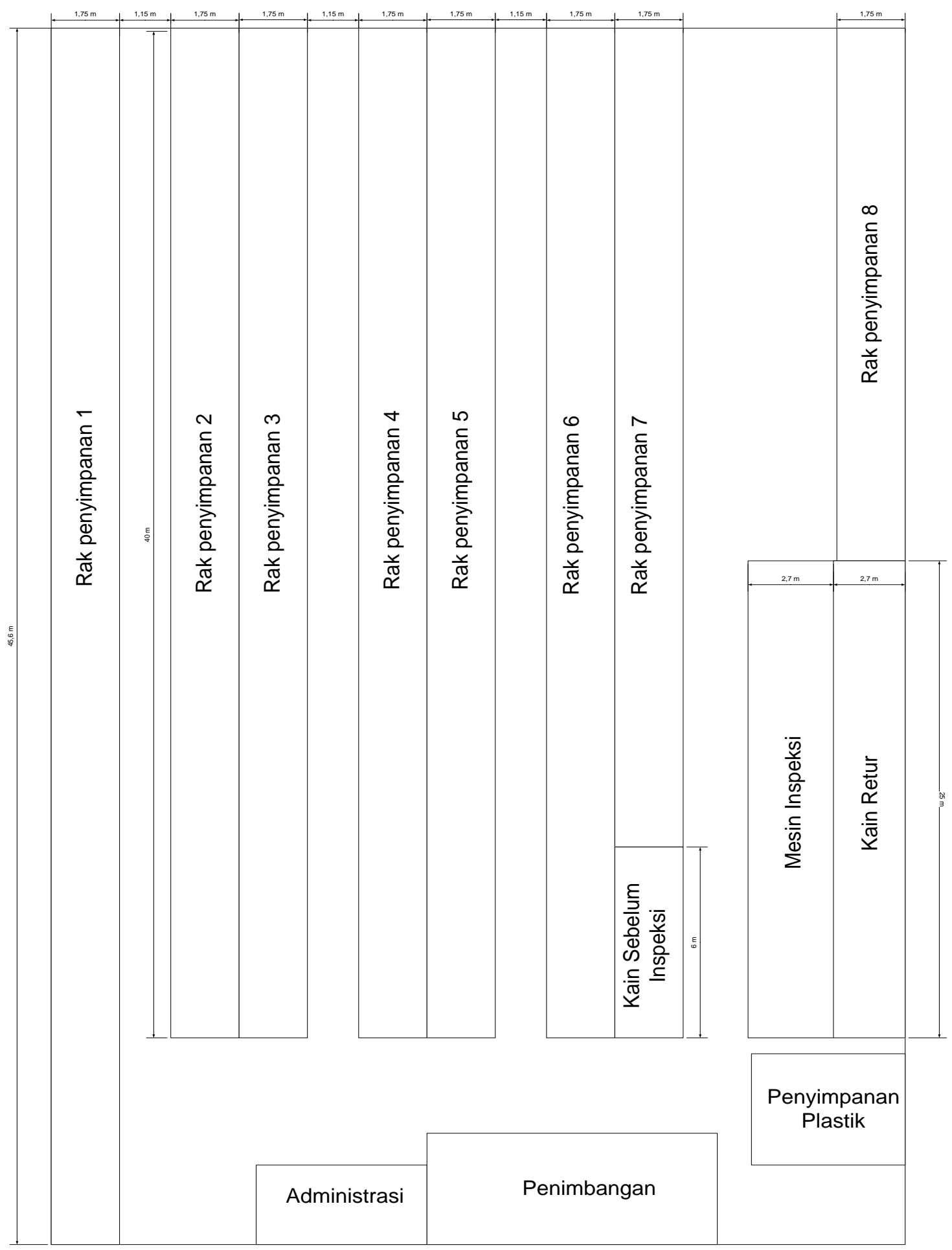

Gambar 5. Tata Letak Gudang Usulan 